\title{
Corrigendum
}

\section{A NEW TYPE OF CITIZEN: YOUTH, GENDER, AND GENERATION IN THE GHANAIAN BUILDERS BRIGADE - CORRIGENDUM}

Jeffrey S. Ahlman

I0.IOI7/SoO218537I2000047 Published by Cambridge University Press, 26 April 20 I 2.

In the above publication, ${ }^{\mathrm{I}}$ six references (five on page 102 and one on page ro4) refer to East Germany. These should read West Germany. The author apologises for this error.

I J. Ahlman, 'A new type of citizen: youth, gender, and generation in the Ghanaian Builders Brigade', The Journal of African History, 53:I (20I2), 87-I05. doi: I0.IOI7/S002 I 8537 I 2000047 